${ }^{\text {I }}$ Departamento de Sociologia,

Universidade Nacional de Quilmes, Argentina

ablanco@unq.edu.ar

II Departamento de Sociologia,

Universidade de São Paulo (USP), Brasil

ljackson@usp.br

Alejandro Blanco'

Luiz Carlos Jackson"

\title{
FLORESTAN FERNANDES NO ESPELHO DE GINO GERMANI *
}

Espelhada na trajetória de Gino Germani (I9I I-I979), a de Florestan Fernandes (I920-I995) revela aspectos possivelmente não problematizados anteriormente. Este trabalho realiza esse movimento inscrevendo os dois personagens nos contextos de institucionalização da sociologia na Argentina e no Brasil, nos quais lideraram, como se sabe, projetos acadêmicos muito destacados e centrais à legitimação dessa disciplina nos dois países. ${ }^{\mathrm{I}}$

No contexto latino-americano, a análise comparada dos casos brasileiro e argentino se justifica, em primeiro lugar, porque neles prevaleceram iniciativas voltadas ao desenvolvimento da sociologia concebidas e implantadas nacionalmente, originadas pela inserção do ensino e da pesquisa no interior de instituições universitárias previamente existentes ou em novas universidades e escolas superiores. Sob tais aspectos, os casos do Chile e do México podem ser contrapostos, por razões distintas. No primeiro, o desenvolvimento da disciplina teve seu lastro mais importante em iniciativas transnacionais. $\mathrm{O}$ exemplo da Faculdade Latino-Americana de Ciências Sociais (FLACSO) é, a esse respeito, emblemático. A instituição resultou de arranjos internacionais e não de uma iniciativa predominantemente nacional. Uma evidência disso reside no fato de os primeiros três diretores da Escola Latino-Americana de Sociologia (ELAS), primeiro programa de pós-graduação da FLACSO, terem sido estrangeiros. ${ }^{2}$ As iniciativas locais de Eduardo Hamuy, diretor do Instituto de Sociologia da Universidade do Chile, envolvido com a defesa de uma sociologia moderna 
e empírica, não se concretizaram em um programa amplo de pesquisa, nem na institucionalização do ensino da disciplina como um curso autônomo. Talvez uma exceção tenha sido a Escola de Sociologia da Universidade Católica do Chile, dirigida pelo sacerdote jesuíta de origem belga, Roger Vekemans, que, durante a década de I960, cumpriu um papel central na formação e no treinamento dos sociólogos chilenos. Mas nesse caso, também, foram decisivos os apoios externos, propiciados pela rede de contatos da Igreja Católica, que favoreceu a incorporação dos primeiros professores, todos eles estrangeiros (Brunner, I985).

No México, apesar do empenho de Lucio Mendieta y Núñez e do espanhol José Medina Echavarría desde o final dos anos de i93o e do forte apoio estatal a essas iniciativas - destacando-se a importância de instituições públicas como a editora Fondo de Cultura Económica e a Revista Mexicana de Sociología, que repercutiram em toda a América Latina -, isso não gerou internamente um processo de institucionalização consistente. A experiência mais ambiciosa, dirigida por Medina Echavarría, o Centro de Estudos Sociais do Colégio do México, fracassou depois de três anos de funcionamento, entre I943 e I946 (Morcillo Laiz, 2008; Blanco, 2010). Outra tentativa se deu com a criação de Escola Nacional de Ciências Políticas e Sociais da Universidade Nacional Autônoma do México (UNAM), criada em I95I, mas esse empreendimento acabou não gerando uma organização acadêmica empenhada na formação de cientistas sociais, mas, sim, na preparação de postulantes à carreira diplomática (Reyna, I979; Castañeda, I990). Seria apenas a partir de I960 que um impulso mais efetivo teria lugar nesse país, destacando-se as iniciativas de Pablo González Casanova nesse processo (Reyna, 2007).

Em segundo lugar, no Brasil e na Argentina a sociologia institucionalizouse como disciplina científica no interior da universidade, permitindo uma articulação mais efetiva do ensino e da pesquisa. Tais condições foram propícias ao surgimento de lideranças institucionais e intelectuais, tais como as de Raúl Orgaz, Ricardo Levene, Alfredo Poviña e Gino Germani, na Argentina; Donald Pierson, Luiz de Aguiar Costa Pinto, Alberto Guerreiro Ramos, Roger Bastide, Maria Isaura Pereira de Queiroz e Florestan Fernandes, no Brasil. Em outros termos, o desenvolvimento pioneiro de organizações acadêmicas modernas 3 nesses países favoreceu uma orientação predominantemente científica nessa disciplina.

Nos dois casos, em terceiro lugar, uma nova cultura intelectual foi gerada, caracterizada pela exigência da profissionalização, pela valorização do trabalho em equipe, pela imposição de uma linguagem científica (Arruda, I995), pela defesa do rigor teórico e da fundamentação empírica, pela fixação de critérios comuns de avaliação e pelo desenvolvimento de projetos acadêmicos e de programas coletivos de pesquisa. Finalmente, em ambos, mais precisamente nas cidades de São Paulo e em Buenos Aires, constituíram-se empreendimentos muito próximos ao que se convencionou designar como "escola" (Tiryakian, 
I979; Bulmer, I984), ou seja, um grupo intelectual formado por líder e discípulos - reunidos em torno de ideias, técnicas, programas e disposições normativas -, que pensam sua atividade como uma missão. Tais inovações relacionaram-se, sobretudo, aos nomes de Gino Germani, na Argentina, e de Florestan Fernandes, no Brasil, "lideranças carismáticas" que se impuseram quase ao mesmo tempo, nas décadas de I950 e I960. Entender os condicionantes envolvidos na emergência desses dois "chefes de escola" ${ }^{4}$, pontuando semelhanças e diferenças entre tais experiências, é o objetivo central deste trabalho.

\section{GINO GERMANI: ENTRE POLÍTICA E CIÊNCIA}

De origem social modesta, Gino Germani foi filho único de um alfaiate e velho militante socialista e de uma descendente de camponeses católicos, criado em um bairro de classe média baixa em Roma. No ano de I934, quando tinha 23 anos, emigrou para a Argentina depois de ser preso por conta de sua militância antifascista (Germani, 2004). Em Roma havia concluído estudos secundários em contabilidade numa escola técnica, complementados pela graduação incompleta em economia na Universidade de Roma. Já na Argentina, integrou-se em grupos da comunidade antifascista e publicou alguns ensaios sobre o fascismo em periódicos da comunidade italiana desse país. Enquanto trabalhava no Ministério da Agricultura ingressou no curso de filosofia da Faculdade de Filosofia e Letras (FFyL) da Universidade de Buenos Aires (UBA) em I938, e pouco antes de se graduar, iniciou sua carreira como sociólogo no Instituto de Sociologia da UBA.

$\mathrm{Na}$ Argentina, o ensino de sociologia fora instituído precocemente na universidade, no interior dos cursos de filosofia e de direito, primeiramente na Faculdade de Filosofia e Letras (FFyL) da Universidade de Buenos Aires (I898) e até I920, aproximadamente, em todas as universidades do país (Poviña, I94I), nas quais lecionaram reconhecidos membros da elite intelectual argentina, como Ernesto Quesada, Juan Agustín García e Carlos Octavio Bunge. A mais antiga universidade argentina foi criada durante o período colonial, em I6I3, na cidade de Córdoba. No Brasil, durante o Império, que seguiu a reforma educacional napoleônica na França, foram criadas faculdades ou escolas superiores isoladas, não integradas em universidades, que apenas surgiriam nos anos de I930, apesar de iniciativas anteriores frustradas (Cunha, 2007). Na Argentina, no começo do século XX, já havia cinco universidades - Córdoba, I6I3; Buenos Aires, I82 I; La Plata, I897; Santa Fé, I899; Tucumán, I9I4-, embora estas resultassem de iniciativas e concepções educacionais distintas (Prado, 2000). A criação das últimas inscreveu-se numa política educacional abrangente e democratizante (em todos os níveis), ocorrida nas últimas décadas do século XIX, voltada ao estabelecimento de um sistema de educação pública, que diminuiu consideravelmente o analfabetismo e ampliou sensivelmente o acesso ao ensino superior. 
O estudo superior nos dois países, durante o século XIX, restringia-se às carreiras tradicionais de direito, medicina e engenharia, orientadas por uma educação de cunho profissionalizante, mas foi no seu interior que as elites intelectuais e políticas foram formadas em ambos os casos. Na Argentina, com a criação da FFyl da UBA, em I896, a formação universitária ganharia uma vertente menos instrumental. Uma diferença fundamental entre a FFyL e a Faculdade de Direito residia no fato de que, na primeira, a carreira acadêmica passava a ser vista não mais como um apêndice da vida profissional realizada fora da universidade, como ocorria com os professores da segunda, mas como o seu centro. De tal modo, emergiria progressivamente nessa instituição a figura do "intelectual acadêmico" (Coser, I968). Tais diferenças se ancoravam em recrutamentos sociais distintos: prevaleciam os membros de famílias tradicionais "criollas" nos cursos de direito; os filhos de imigrantes em ascensão nos de filosofia e de letras.

Além das implicações políticas da reforma universitária de I9I8 - que levou à democratização dos mecanismos de gestão das universidades e tornou a universidade e os estudantes em protagonistas da vida pública argentina -, dela derivaram mudanças na estrutura e no funcionamento das organizações acadêmicas (Buchbinder, 2005). Foram, assim, reforçadas as condições para o desenvolvimento de carreiras acadêmicas propriamente ditas. O plantel de professores foi renovado, nele ingressando membros das classes médias emergentes, provenientes, sobretudo, de famílias de imigrantes. Nesse contexto, ainda, foram contratados professores estrangeiros para distintas disciplinas - a Argentina e o México se beneficiaram do exílio de professores espanhóis durante o franquismo - como os filólogos Américo Castro e Amado Alonso, o matemático Julio Rei Pastor (os três na UBA) e o filósofo Manuel García Morente (em Tucumán). Finalmente, visando impulsionar a atividade científica, foram criados numerosos institutos de pesquisa na maioria das universidades. Somente na FFyL da UBA, entre I92 I e I942, surgiram I6 institutos (Buchbinder, I997).

Dessas inovações derivou um impulso mais efetivo para o desenvolvimento da sociologia argentina, a partir da criação do Instituto de Sociologia da UBA, em I940, no qual Germani iniciou sua carreira de sociólogo, apoiado diretamente por Ricardo Levene, então diretor do Instituto, que fora seu professor de sociologia e de quem havia se aproximado. Esta relação viabilizou suas primeiras atividades de pesquisa e seus primeiros artigos no Boletín del Instituto de Sociología sobre a morfologia da sociedade argentina, nos quais pode mobilizar o conhecimento então atípico em estatística adquirido na Itália, que contrastava com a tradição pouco científica que até então prevalecera na sociologia, voltada em grande parte a uma história tradicional das ideias, centrada no pensamento social argentino.

Nessa primeira etapa de sua carreira, transcorrida aproximadamente na primeira metade da década de I940, o ítalo-argentino introduziu um novo estilo de trabalho, caracterizado pelo maior embasamento empírico e pelo instru- 
mental estatístico mobilizado, o que determinou sua indicação por Levene para dirigir uma das linhas de pesquisa do Instituto, intitulada Investigaciones sobre la morfología y aspectos estadísticos de la realidad argentina contemporánea, que recolhia informações sobre a estrutura social argentina, publicadas regularmente no Boletín. Também por meio de Levene, Germani participou da comissão encarregada de realizar o IV Censo Nacional, que motivou, igualmente, a publicação de artigos referidos a essa experiência. Finalmente, nesses anos dirigiu uma importante pesquisa empírica sobre a classe média de Buenos Aires, apoiada nos marcos de referência da sociologia de Chicago. Cabe lembrar que tais trabalhos foram acompanhados por reflexões de ordem teórica e metodológica muito inovadoras em relação às que eram então produzidas pelos sociólogos argentinos, e que vieram à tona em conferências e artigos.

Essas primeiras tentativas realizadas no âmbito do Instituto, contudo, não prosperaram imediatamente, em função dos entraves ligados à própria estrutura institucional do mesmo e de sua vinculação direta à Cátedra, que não previa nenhuma possibilidade de remuneração aos pesquisadores. De tal maneira, os passos iniciais de Germani como sociólogo foram dados num terreno desfavorável, se levadas em conta as possibilidades de profissionalização que propiciavam os institutos. O ano de 1945 pode ser tomado como um ponto de inflexão entre esses estudos de iniciação e sua obra madura posterior. O texto que marca essa transição é "Anomia y desintegración social", que introduziu temas (modernização, industrialização) retomados futuramente e esboçou um novo cânone teórico que iria guiar seus trabalhos individuais e os de seu grupo - como também faria Florestan Fernandes no Brasil, sobretudo em Fundamentos empíricos da explicação sociológica -, que recuperava a sociologia clássica francesa de Durkheim, além da norte-americana e dos aportes da psicologia social. No ano seguinte, Germani prestou concurso na universidade para professor adjunto da Cadeira de Sociologia da Faculdade de Ciências Econômicas da UBA. A derrota ocorreu, provavelmente, em função dos entraves políticos já presentes no início das primeiras duas presidências de Perón (I946-I955). A monografia que escreveu para esse concurso antecipava argumentos que dez anos depois reapareceriam no livro manifesto La sociologia científica. Apuntes para su fundamentación (I956), orientada pela possibilidade de constituir a sociologia como "ciência empírica da realidade social" (Germani, I946: 3). Do que vimos até agora, é possível inferir que Germani já tinha em mente, nessa época, o contorno geral de seu projeto intelectual que anos mais tarde ganharia a forma de um programa de pesquisa desenvolvido na universidade pós-peronista.

Durante o peronismo a universidade sofreu intervenção direta. Muitos professores foram afastados (423) e outros se retiraram (823) da universidade (Luna, 1987), implicando uma profunda divisão entre intelectuais e governo. Por outro lado, o ingresso universitário geral foi triplicado, de 51.272, em 1947, para I43.542, em I955 (Mangone \& Warley, I 984), incrementando o acesso amplo dos 
setores médios ao ensino superior. Germani, então vinculado ao Instituto de Sociologia, saiu também da universidade, depois de ser acusado de professar ideias comunistas. Nesse quadro, as principais posições do campo acadêmico, especialmente na FFyL, foram ocupadas por professores simpáticos a Perón e provenientes do nacionalismo católico.

Não obstante, durante esse período, a sociologia logrou expandir-se nacionalmente e articulou-se com organismos internacionais em função da militância exercida por Alfredo Poviña, destacando-se a fundação da Associação Latino-Americana de Sociologia (Blanco, 2005). Ao mesmo tempo, constituiu-se um circuito alternativo de legitimação intelectual fora da universidade, articulado ao mercado editorial argentino, que teve, a partir da década de i930, uma notável expansão. Foi típica, nesse sentido, a atuação de Gino Germani à frente das coleções "Ciência e Sociedade" (Editora Abril) e "Biblioteca de Psicologia Social e Sociologia" (Paidós), por meio da qual o sociólogo introduziu na Argentina um conjunto de autores e obras afinados com temas e abordagens que desenvolveria posteriormente. As editoras constituíram um espaço decisivo de atuação para os intelectuais excluídos da universidade pelo peronismo (Blanco, 2006).

Em tal direção, uma característica peculiar da estrutura do campo intelectual argentino no período era sua natureza mista, que permitia o trânsito entre as posições oficiais e aquelas inscritas em iniciativas privadas. A manifestação mais típica dessa configuração foi o Colégio Livre de Estudos Superiores. Sua criação ocorreu pouco antes do golpe de I930 e, durante o peronismo, o colégio agregaria o núcleo da elite intelectual argentina, que convergia na sua oposição (Neiburg, I998). Nessa instituição, Germani lecionou seus primeiros cursos de sociologia, ganhando prestígio intelectual e tecendo alianças políticas que seriam decisivas à concretização de seu projeto científico entre a segunda metade da década de i950 e a primeira da década seguinte. Ainda durante o peronismo, assumiu uma atitude intelectual mais agressiva, enfrentando diretamente sociólogos já estabelecidos, como Alfredo Poviña, Renato Treves, Alberto Baldrich, Francisco Ayala, Raúl Orgaz, Miguel Figueroa Román, entre outros, durante o Primer Congreso Latinoamericano de Sociología, organizado pela Associação Latino-Americana de Sociologia, que ratificou a liderança institucional dessa geração de sociólogos, ao mesmo tempo em que a viu ameaçada diante da ascensão de Germani.

Sua participação nos círculos intelectuais de oposição ao regime o favoreceria após a Revolução Libertadora, que derrubou Perón em I955. Esse evento representou um ponto de viragem na carreira acadêmica de Germani, opondo um primeiro período caracterizado pelo forte investimento na formação intelectual e pelas tentativas de ingressar profissionalmente num sistema universitário então afetado por constantes intervenções políticas, a um segundo, no qual o sociólogo ocupou posição de líder do processo de modernização e de inserção institucional da sociologia argentina. Deve-se notar que os dois perí- 
odos podem ser demarcados, também, por seu segundo casamento, aos 43 anos de idade, com Célia Carpi (o casal teria dois filhos), ocorrido em I954, evento certamente relacionado à estabilização de sua vida profissional. ${ }^{5}$

Nessa nova conjuntura política, Germani conseguiu impor-se de maneira mais efetiva no interior da instituição acadêmica, beneficiado pela reforma pós-peronista que modernizou a estrutura universitária, principalmente na UBA. Uma série de iniciativas, destacando-se a criação do Conselho Nacional de Investigações Científicas e Técnicas (CONICET) e a promoção do regime de dedicação exclusiva, conduziu à integração mais efetiva do ensino e da pesquisa. Com o apoio do então reitor, o historiador José Luis Romero, e das lideranças estudantis, Germani assumiu a Cátedra e o Instituto de Sociologia e, em I957, empenhou-se diretamente na criação do curso de graduação em sociologia. Uma vez consolidadas tais mudanças, que propiciaram a ele uma posição central no campo da sociologia argentina, as polarizações já existentes nos períodos anteriores foram radicalizadas. O sociólogo ítalo-argentino reforçou a defesa da "sociologia científica" contra a chamada "sociologia de cátedra". Esta vicejava na maioria das universidades do interior do país e era liderada por Poviña (Blanco, 2006). Germani contava, não obstante, com o apoio de um conjunto de empreendimentos intelectuais na América Latina (Blanco, 2007), muito afinados com o seu, dos quais tomou parte ativa. Foi o caso do movimento que deu origem, nos anos de I950, à criação da Faculdade Latino-Americana de Ciências Sociais (FLACSO) e do Centro Latino-Americano de Pesquisa em Ciências Sociais (CLAPCS). Embora lograsse impor o seu projeto acadêmico, identificado com o processo de "desperonização" (Neiburg, I998) da sociedade argentina, as disputas foram intensas porque boa parte das instituições, com exceção da UBA, que estruturavam a sociologia argentina estava controlada por seus adversários no mundo acadêmico. No entanto, os embates propriamente intelectuais foram travados com oponentes que não estavam no interior da universidade. O grupo de Poviña não tinha um programa de pesquisa com o qual pudesse desafiar Germani. Por isso, as interpretações deste último sobre a experiência argentina rivalizaram com a tradição ensaística, embora não frontalmente. ${ }^{6}$

De qualquer modo, a legitimidade de Germani estribou-se no programa de pesquisa que liderou no interior da universidade, voltado ao entendimento do processo de modernização argentino. O primeiro passo dado nessa direção foi a caracterização da estrutura social do país, tema de seu primeiro livro, Estructura social de la Argentina. Análisis estadístico (I955), que o consagrou como um dos principais renovadores da cena intelectual do país naquele momento. O segundo ocorreu com suas interpretações sobre a imigração massiva na formação da Argentina moderna e sobre a gênese e o significado social e político do peronismo, reunidas no livro Política y sociedad en una época de transición (I962a). Curiosamente, de acordo com confissão tardia de Germani (I978), essa última análise teria se originado de uma encomenda do presidente Pedro Eu- 
genio Aramburu, em 1955, meses depois da derrubada de Perón, que o teria consultado sobre a "possibilidade e a forma" de uma campanha de desperonização. Disso resultou o texto "La integración de las masas a la vida política y el totalitarismo" (I956a), ' que seria incorporado ao livro posteriormente. A resposta de Germani, provavelmente, decepcionou o presidente, uma vez que seu diagnóstico constatou a incorporação incontornável da classe trabalhadora à vida política do país.

Germani interpretou o surgimento do peronismo como um fenômeno político e social derivado das grandes transformações em curso no país, sobretudo, desde a década de I930, impulsionadas pela industrialização incipiente no período e pelas mudanças da estrutura social correspondentes. Quanto a este último ponto, teria sido decisiva a incorporação de um novo contingente de trabalhadores, oriundo de migrações internas, das províncias mais tradicionais para os centros urbanos, principalmente Buenos Aires. O autor comparou o peronismo com os regimes totalitários europeus, questionou as causas possíveis da sua emergência e avaliou seu significado político. Embora todos esses regimes tivessem apoio das massas, no caso argentino a base de sustentação política não seriam as classes médias baixas, como na Alemanha e na Itália, mas sim as classes trabalhadoras urbanas e rurais. Em função disso, na Europa, a ideologia de tais regimes seria contrária às classes trabalhadoras, enquanto na Argentina, favorável a elas. Como teria se dado, entretanto, a vinculação entre as classes trabalhadoras e Perón?

O argumento de Germani associa esse fato ao já mencionado crescimento e transformação da composição social da classe trabalhadora, em função do movimento de migração interna. Em tais condições, apenas uma parcela do operariado urbano (de origem estrangeira) se fazia representar politicamente pelos movimentos tradicionais de esquerda, enquanto o contingente recentemente incorporado, oriundo do interior do país, seria atraído pelo peronismo. A adesão dessas massas a um líder autoritário como Perón se explicaria pela persistência de uma cultura política tradicional, paternalista, própria dos migrantes. Mas isso não teria ocorrido em função de vantagens materiais e imediatistas proporcionadas pelo regime e sim pela incorporação concreta do trabalhador como sujeito político, consciente de seu papel na vida nacional e capaz de afirmar seus direitos em relação aos empregadores. O significado político do peronismo só poderia ser alcançado se levados em conta tais aspectos de seu funcionamento: politicamente regressivo por seu autoritarismo, seria progressista por infundir nos trabalhadores verdadeira consciência de classe, perceptível não apenas na dimensão coletiva, mas também psíquica, e por proporcionar a possibilidade de afirmação da dignidade pessoal no mundo do trabalho.

Política y sociedad en una época de transición incluía, também, uma análise sobre a imigração massiva no Rio da Prata e de seu impacto no processo de modernização do país. Em torno dessa questão central à tradição intelectual 
argentina, ${ }^{8}$ Gino Germani e o historiador José Luis Romero (I909-I977) iniciaram uma parceria intelectual que desembocaria num projeto coletivo de grande repercussão, que contou também com a participação de Tulio Halperin Donghi (Romero, Germani \& Halperin Donghi, I958). Germani e Romero haviam se aproximado no Colégio Livre de Estudos Superiores durante o peronismo e seria durante a gestão de Romero como reitor interventor da UBA que a sociologia se institucionalizaria propriamente por meio da criação do curso de graduação em sociologia ( I957), no interior do qual o historiador lecionou a disciplina de história social, muito celebrada pelos alunos das primeiras turmas de sociólogos da FFyl. Essa aliança os favorecia por motivos distintos. Não obstante o papel destacado que teve como reitor interino da UBA logo após a queda do peronismo, Romero ocupava um lugar marginal no interior de sua disciplina, cujas principais posições continuavam sendo controladas pelos historiadores ligados à Nova Escola Histórica (Halperin Donghi, I980; Devoto, I993; Miguez, I 993). ${ }^{9}$ Por conta disso, a aproximação com a sociologia lhe proporcionaria uma nova fonte de legitimação. Para Germani, a relação com a história implicava um nexo com a tradição e uma ampliação de seus recursos institucionais. Da pesquisa coletiva, resultaram os livros Argentina, sociedad de masas (Germani, Graciarena \& Halperin Donghi, I965), e Los fragmentos del poder (Halperin Donghi \& Di Tella, I969), evidências do alcance dessa aliança de sociólogos e historiadores, que renovou as duas disciplinas (Blanco, 2013).

Mas as visões de Romero e Germani sobre a imigração eram distintas e isso certamente é compreensível se levadas em conta as biografias de ambos. Foram diferentes, sobretudo, os itinerários intelectuais que percorreram. Romero era filho de imigrantes espanhóis remediados e formou-se na Faculdade de Humanidades da Universidade de La Plata. Seu irmão, Francisco, nascido na Espanha, quinze anos mais velho do que ele, então um dos filósofos mais consagrados da América Latina, foi quem o iniciou no conhecimento da tradição filosófica e sociológica alemã e o introduziu em círculos intelectuais prestigiosos. Romero desfrutou, por exemplo, de um convívio estreito com o importante intelectual dominicano Pedro Henríquez Ureña, que o indicou ao editor da Fondo de Cultura Económica, Daniel Cosío Villegas, que procurava alguém que escrevesse uma história das ideias políticas na Argentina. Dessa encomenda resultou o primeiro livro de Romero sobre a Argentina (ele era até então um medievalista), Las ideas políticas en Argentina (I946). Também por seu estilo ensaístico, o historiador aspirava, provavelmente, inscrever-se como um herdeiro da tradição intelectual argentina, em especial daquela representada pelas figuras de Sarmiento e Mitre, além de Martínez Estrada. Germani, ao contrário, era um intelectual quase sem ascendentes no interior da tradição nacional. Romero se aproximava, ainda, do movimento conhecido como "reação espiritualista", encampado na Argentina pelo filósofo espanhol Ortega y Gasset. De tal maneira, afastava-se de uma perspectiva "científica" na historiografia, en- 
carnada na década de 1930 pela Nova Escola Histórica. Defenderia, nos anos de I950, por meio da revista Imago Mundi, uma história cultural, apoiada em autores da filosofia da história alemã do final do século XIX como Rickert, Windelband, Dilthey e Simmel, dos quais Germani se afastava por distinguirem as ciências naturais das ciências do "espírito", dificultando as possibilidades de constituição da sociologia em ciência.

Com a publicação de Las ideas políticas en Argentina, o tema da imigração ganhou um lugar que não tinha até então na historiografia e na sociologia, apesar da importância desse fenômeno para o desenvolvimento da vida intelectual e artística do país no século XX. O historiador traçou aí o inventário da maioria dos aspectos que mais tarde fariam parte do projeto coletivo de pesquisa (Romero, Germani \& Halperin Donghi, I958) e que seriam incorporados nos trabalhos individuais de Germani (1962b; I964). Como dissemos, entretanto, as interpretações que propuseram sobre o fenômeno imigratório foram bem diferentes. Havia concordância em relação aos traços gerais desse processo. A imigração estaria diretamente vinculada ao desenvolvimento econômico, ao crescimento demográfico e à urbanização. Romero, entretanto, tinha uma visão pessimista (apesar de ser ele próprio filho de imigrantes), herdada do clima intelectual iniciado com a reação nacionalista do começo do século XX e apoiada na constatação do caráter marginal dos grupos imigrantes. A partir da mesma caracterização geral, Germani atribuiu um significado distinto ao fenômeno. Ao invés de supor a marginalização política e social do imigrante, defendeu a ideia de que teria ocorrido um processo bem-sucedido de integração social, favorecido pela composição predominantemente masculina dos afluentes (fato que restringiria a possibilidade de ocorrerem casamentos no interior dos próprios grupos), pela interrupção da imigração massiva por volta de i930 e pelas altas taxas de mobilidade social ascendente. ${ }^{\text {Io }}$

Antes de resumirmos a análise proposta por Germani para o processo de modernização da América Latina, retomemos o itinerário que o conduziu a esse tema e que foi descrito acima. Vimos a importância da análise que realizou sobre a experiência peronista; ela é reveladora, entretanto, da lógica do sistema acadêmico no qual a sociologia estava inscrita e, também, das dificuldades enfrentadas ao longo de sua carreira. O debate público sobre o peronismo e o fato do sociólogo tê-lo constituído exitosamente como tema acadêmico, comprometendo diretamente a sociologia com uma questão política de alcance nacional, é indicativo da imbricação dos campos político e acadêmico, visível também nas etapas prévias de sua carreira que transcorreu fora da universidade, então sob intervenção peronista. ${ }^{11}$ Germani sequer realizou o doutorado, ganhando reputação intelectual, também, em função do alinhamento político com os intelectuais antiperonistas no CLES. A defesa da sociologia científica que protagonizou, não implicou o alheamento em relação às questões políticas do momento; ao contrário, sintonizou-se com elas. 
Contrastado com o itinerário percorrido por Germani, o de Florestan Fernandes cumpriu rigorosamente as etapas de uma formação científica - graduação, mestrado, doutorado, livre-docência e cátedra -, iniciado com temas distanciados das conjunturas políticas imediatas e muito favoráveis à defesa de uma perspectiva científica estrita - folclore e etnologia -, revelando que no Brasil, mais especificamente em São Paulo, as esferas acadêmica e política estavam relativamente separadas. Sua aproximação com os temas candentes da política nacional só ocorreria na década de i960, depois de consolidada sua posição (e de seu grupo) na universidade. Em suma, as escolhas temáticas de Germani teriam sido condicionadas pelas conjunturas políticas, enquanto as de Florestan pelas orientações científicas que então se impunham nas duas instituições universitárias em que se formou. Sobre essa diferença, vale lembrar que o final do varguismo no Brasil não levou a uma incorporação dos temas políticos pela sociologia paulista (no Rio de Janeiro o debate sociológico se politizou), enquanto todo o debate intelectual argentino posterior ao peronismo, incluindo o da sociologia, foi diretamente pautado pelo tema da "desperonização" da sociedade (Sarlo, 200I; Altamirano, 200I).

Desde o final da década de I950, em função tanto dos contextos políticos nacionais, como de projetos empreendidos por instituições (acadêmicas ou não) internacionais, os temas do desenvolvimento econômico e da modernização se impuseram como eixos em torno dos quais a sociologia da América Latina se desenvolveu no período (Oliveira, I995; Villas Boas, 2006). Nesse quadro se inscrevem os trabalhos de Germani que seriam reunidos no livro Sociologia de la modernización (I969). O conjunto de textos oferece uma análise sistemática e nuançada do processo de transformações sociais, econômicas e políticas transcorridas no século XX, sobretudo na Argentina, mas atento ao que estava em curso nos outros países da América Latina. A expectativa de encadeamento sincrônico das mudanças nesses diversos níveis da realidade (desenvolvimento econômico, democratização, racionalização, secularização do comportamento) é desfeita e o autor busca uma compreensão dos arranjos concretos, como o ocorrido na Argentina, onde teria havido modernização social com desenvolvimento econômico tímido e democratização restrita.

Nessa direção, sua interpretação sobre o peronismo é revista, inserida num quadro mais amplo, que tem como referência as mudanças introduzidas na Argentina desde o final do século XIX, capitaneadas pelas oligarquias dominantes, lastreadas na economia agroexportadora e, decisivamente para o argumento que o autor empreende, no processo de imigração estrangeira e de seu impacto sobre a estrutura e a dinâmica social. Vimos que sua visão a respeito da imigração era otimista e insistia na integração dos contingentes de imigrantes e no incremento da mobilidade social desde o começo do século XX. Para Germani, a sociedade resultante da imigração, caracterizada por altas taxas de mobilidade social, formaria uma classe média numerosa (seu volume 
passou de $5 \%$, em I879, a I4\%, em I895), alterando os padrões tradicionais de estratificação vigentes até então. A "fluidez" da estrutura social (dados os movimentos de ascensão e declínio) a caracterizaria, nos termos do autor, como uma "sociedade aberta". Tal "fluidez" implicaria um alto grau de heterogeneidade na composição das classes média e trabalhadora, debilitando a solidariedade de classe e exercendo uma influência moderadora sobre as orientações políticas. Por isso mesmo, o radicalismo não expressaria demandas extremas, mas reivindicações contidas de reformas sociais. Como o grau de "fluidez" da estrutura social permaneceria alto depois de I930 - apesar do declínio econômico que atinge o setor agroexportador nesse período -, incrementado pela migração interna, também massiva, que atendia à necessidade de mão de obra para a industrialização em curso, o peronismo seria (como o radicalismo para as classes médias) resultante de demandas moderadas dos setores novos do operariado. ${ }^{12} \mathrm{O}$ padrão de modernização da sociedade argentina, portanto, seria determinado pelas altas taxas de mobilidade e pela integração social e política conduzida pelos movimentos "nacionais populares" entendidos, ao mesmo tempo, como sintomas da crise aberta pelos "processos de mobilização" e como respostas aos problemas relativos à integração dos grupos emergentes. Diante de tal interpretação, em relação à crise política que sucedeu ao peronismo e que se prolongaria nas décadas seguintes, Germani constatava o paradoxo de uma estrutura social moderna, mas que não lograva estabilizar um sistema político democrático, entendido como a forma política que deveria corresponder a uma "sociedade aberta" como a argentina.

Resta ainda comentar a atuação institucional de Germani desde o final do peronismo, no contexto da reforma universitária que implicou a criação do curso de graduação em sociologia (I957) e do Departamento de Sociologia (I958). A composição do plantel de professores do Departamento permite entrever as estratégias de recrutamento mobilizadas por ele. De um lado, estavam Carlos Alberto Erro, Norberto Rodríguez Bustamante e Enrique Butelman, provenientes dos círculos intelectuais de oposição ao peronismo, mas que não encarnavam uma perspectiva sociológica moderna. Erro e Bustamante haviam colaborado no jornal La Nación e na revista Sur. O primeiro era autor de ensaios importantes, publicados nos anos de I930, sendo o principal deles Medida del criollismo (I 929); o segundo lecionou no CLES durante os anos do peronismo. Butelman fora um dos criadores da editora Paidós e era um grande amigo de Germani. Esses três professores foram importantes na legitimação inicial do empreendimento, sobretudo, porque estabeleciam uma relação de continuidade com a tradição intelectual. De outro lado, estavam Jorge Graciarena, Torcuato Di Tella, Miguel Murmis e Juan Carlos Marín, um grupo de jovens estudantes, os quatro ligados ao Partido Socialista. Se essa filiação era um fator importante para acomodar a sociologia no interior das forças em disputa no contexto pós-peronista (o que se refletia diretamente na universidade), eles diferenciavam-se dos primeiros por 
aproximarem-se mais propriamente do projeto intelectual de Germani, inclinação certamente relacionada com a origem universitária recente dos quatro. Um dos membros importantes do Instituto, entretanto, destoava dos perfis indicados acima. José Luis de Imaz era um intelectual proveniente dos círculos católicos e nacionalistas e sempre foi visto com certa desconfiança por seus colegas. ${ }^{\mathrm{I}}{ }^{3}$

Devemos enfatizar que a aliança estabelecida por Germani com o movimento estudantil - lembramos que na Argentina, desde a Reforma Universitária de I9I8, apesar das interrupções, os estudantes participam diretamente da gestão da universidade -, foi um recurso decisivo para consolidar a nova disciplina. Alem dos citados, outros jovens que seriam incorporados ao Departamento haviam participado ativamente, durante os últimos anos do peronismo nas diversas instâncias da política estudantil, especialmente como dirigentes no Centro de Estudantes de Filosofia e Letras, que editava a revista Centro. Nesta, aliás, Germani publicou a pesquisa sobre a situação social dos estudantes universitários, que contou com apoio do Centro (Germani, I956b). Outra característica de sua gestão no Departamento e no Instituto de Sociologia foi a exclusão de todos aqueles que haviam ocupado posições acadêmicas e institucionais na sociologia da UBA durante o peronismo.

Visando a modernização da pesquisa e do ensino, Germani enviou boa parte dos membros do grupo ao exterior, principalmente aos Estados Unidos (o que entendia como um passo importante para se adquirir uma mentalidade propriamente científica), país considerado por ele como o centro da sociologia moderna. ${ }^{14}$ Além disso, convidou professores estrangeiros para lecionar no Departamento e participar de pesquisas do Instituto e estabeleceu acordos de colaboração com instituições internacionais. Dando continuidade aos empreendimentos editoriais mencionados, nas editoras Abril e Paidós, mas de maneira mais pragmática, Germani montou um sistema próprio de publicações do Departamento e do Instituto, visando suprir a precariedade da literatura especializada. Como ocorreu em São Paulo, desde a iniciativa precursora de Emílio Willems na revista Sociologia, seguida por outras de Donald Pierson, Florestan Fernandes, Fernando Henrique Cardoso, Octávio Ianni (entre outros), vários livros de textos foram organizados e publicados para viabilizar o ensino da sociologia até o final dos anos de ig6o. Além disso, foram editados os Cuadernos, que publicavam pesquisas do Instituto e obras estrangeiras, e as Publicaciones Internas, que veiculavam materiais produzidos internamente.

O curso de graduação tinha uma orientação explícita para a pesquisa, verificada pela existência de duas matérias obrigatórias, uma sobre estatística, outra sobre métodos e técnicas de pesquisa. Os alunos eram obrigados a participar das atividades do Instituto de Sociologia, acumulando ao menos roo horas de atividade de pesquisa (realizando surveys, entrevistas, codificação de dados, elaboração de quadros), que obrigavam os alunos a percorrerem as etapas típicas de uma investigação científica. ${ }^{15}$ Para fazer frente a essas exigências, 
o Instituto foi convertido num centro de treinamento de pesquisadores e numa organização complexa e fortemente burocratizada.

Aparentemente, em termos comparativos, nenhuma figura concentrou tanto poder nas ciências sociais brasileiras em seu período de fundação. Numa escala menor, já que estava à frente de uma instituição privada e de dimensão reduzida se comparada à UBA ou à USP, Donald Pierson exerceu função similar no interior da Escola Livre de Sociologia e Política (ELSP), entre o final dos anos de 1930 e meados da década de I950. Na USP, em função do sistema de cátedras vigente até o final da década de I960, os regentes tinham muita autonomia em relação às disciplinas que ministravam e às atividades que exigiam dos professores assistentes e auxiliares, mas o poder detido por eles se restringia, predominantemente, ao interior das Cadeiras que regiam, embora pudessem tentar ultrapassar esse âmbito por meio de disputas diretas ou indiretas com outros catedráticos, como fez Florestan Fernandes.

A interrupção do processo de modernização da sociologia iniciou-se na Argentina com o golpe de Estado de i966, que implicou um período de intervenções drásticas nas universidades - diferentemente do que ocorreu no Brasil, onde a ditadura militar de I964 moveu perseguições pontuais, mas também favoreceu a expansão do sistema de ensino superior em geral e das ciências sociais em particular (Ortiz, I990). O Departamento de Sociologia da Universidade de Buenos Aires foi praticamente desmantelado. Dos 28 professores que o integravam em I966, restaram 4 em I967. O Instituto de Sociologia, que contava com 29 membros e desenvolvia I5 projetos de pesquisa, foi fechado (García Bouza \& Verón, 1967).

A "sociologia científica" de Germani, que se afastou nesse momento da Argentina, teria seu projeto abortado. A continuidade da pesquisa científica autônoma ocorreu, então, por meio de sua transferência para centros privados de pesquisa (Murmis, 2007; Neiburg, I998), como ocorrera antes, de certa forma, no âmbito do Colégio Livre de Estudos Superiores, e que havia sido preparada por Germani, através dos vínculos estabelecidos com o Instituto Di Tella. Segundo uma pesquisa realizada nessa época, em torno de I 970 a pesquisa em sociologia era realizada em I I centros privados, três dos quais pertenciam àquele Instituto (Kratochwill, I970). Nesse momento, assumiram a docência e os cargos diretivos na universidade professores que defendiam (ou diziam defender) uma "sociologia nacional", que tinha como oponentes as sociologias "marxista" e "científica". As figuras emblemáticas desse período das "cátedras nacionais” foram o sacerdote Justino O'Farrel e Gonzalo Cárdenas, que assumiram em I969 a direção do curso e do Instituto de Sociologia, respectivamente. 


\section{CONTRAPONTO}

Passemos agora a uma comparação entre as trajetórias de Gino Germani e Florestan Fernandes, ${ }^{16}$ lembrando que ambos lideraram processos de legitimação da sociologia e a reivindicaram como ciência aplicada ao entendimento do processo de modernização em curso nos dois países (nas décadas de I950 e I960). Foram "intelectuais acadêmicos" (Coser, I968), envolvidos diretamente nos desafios inerentes aos primórdios da institucionalização universitária dessa disciplina, com a qual se identificaram plenamente e que propiciou a eles, inicialmente destituídos de capital social e cultural, a oportunidade de ascender às posições mais altas e prestigiosas da hierarquia acadêmica. Mas o que os diferenciou de outros líderes que atuaram quase simultaneamente a eles no Brasil e na Argentina (e em outros países da América Latina) foi o fato de ambos terem se constituído e consagrado como "chefes de escola".

Suas carreiras devem ser compreendidas em função das mudanças ocorridas nos sistemas de produção cultural e acadêmica dos dois países, desde meados do século XX, que permitiram a profissionalização mais efetiva da atividade intelectual graças, principalmente, à constituição de organizações acadêmicas modernas em São Paulo e Buenos Aires. Sobre esse processo, alguns condicionantes gerais devem ser mencionados. O primeiro deles relaciona-se com o crescimento demográfico acelerado ocorrido em tais cidades, a partir do final do século XIX, fator morfológico decisivo à constituição de ambas como metrópoles em meados do século XX. Ambas receberam contingentes elevados de imigrantes europeus, ${ }^{17}$ que promoveram a diferenciação de suas estruturas sociais, implicando a emergência de novas classes médias urbanas, ${ }^{18}$ que favoreceram a renovação e a diversificação das atividades e empreendimentos culturais eruditos e populares e incrementaram a formação mais densa de públicos nos dois casos (Prieto, I988; Rivera, I980; Sarlo, I988; Miceli, 200I), embora mais acentuadamente em Buenos Aires. No caso brasileiro, é patente certo deslocamento do eixo da produção cultural, acentuado no decorrer do século XX, do Rio de Janeiro para São Paulo, processo relacionado com o formidável crescimento econômico ocorrido nesta última e a consequente dinamização de seu mercado cultural. Consolidada a proeminência carioca no âmbito político nacional, com a derrota de São Paulo na Revolução de I930 (e em I932), a vida cultural naquela cidade ganhou um impulso notável, tornando-se cada vez mais autônoma e profissionalizada. Isso favoreceu um desenvolvimento sem precedentes em âmbitos aparentemente descolados como o teatro, a literatura, as artes plásticas e as ciências humanas, mas diretamente condicionados pelas transformações mencionadas (Arruda, 200I; Pontes, 20Io). No caso de Buenos Aires, esta cidade nunca teve concorrente em seu país, constituindo-se desde a independência como centro econômico, político e cultural. No Brasil, São Paulo e Rio de Janeiro disputaram o mercado cultural e acadêmico, oscilando 
a balança para um lado ou outro, de acordo com os gêneros e períodos em questão.

Os imigrantes e seus descendentes desempenharam em São Paulo e Buenos Aires um papel decisivo na concretização dos projetos de modernização acadêmica (não apenas para a sociologia) e, significativamente, os personagens aqui comparados se enquadram nesse perfil. A diferenciação social (associada a um processo de desenvolvimento econômico acelerado), catalisada pela imigração ocorrida entre o final do século XIX e as primeiras décadas do século $\mathrm{XX}$, foi um dos condicionantes principais à conversão de projetos educacionais, inicialmente concebidos pelas elites, em modernas empresas acadêmicas afinadas com as demandas de ascensão das novas classes médias (Miceli, I989).

Sabe-se que em São Paulo o desenvolvimento das ciências sociais foi favorecido pela relativa independência da USP em relação aos poderes políticos, dos quais sofreu interferências apenas esporádicas e indiretas, o que implicou a constituição de vida acadêmica profissionalizada e orientada cientificamente (Miceli, I989). No Rio de Janeiro, a sociologia associou-se mais diretamente às disputas políticas e ideológicas do período analisado, o que, apesar da atuação destacada de lideranças como Alberto Guerreiro Ramos e Luís de Aguiar Costa Pinto, dificultou o desenvolvimento mais estritamente científico e prolongado dessa disciplina até o final da década de I960 (Almeida, I989; Vianna, I997). ${ }^{\text {I9 }}$ Sintomaticamente, nenhum desses dois sociólogos alcançaria a cátedra de sociologia na Faculdade Nacional de Filosofia (FNFi) da Universidade do Brasil (Brasil Jr., 2013), onde haviam se formado. Assim, haveria maior proximidade entre essa experiência e a que se deu em Buenos Aires, apesar de que nesta última a imbricação com a política não bloqueou o desenvolvimento de um projeto científico no interior da universidade. Como poderíamos explicar essa outra modalidade, que combina politização do campo acadêmico e desenvolvimento científico na instituição universitária?

Rio de Janeiro e Buenos Aires se aproximavam por serem, então, centros políticos nacionais, o que implicava uma tensão mais pronunciada e constante entre poderes políticos e acadêmicos (diferentemente do que ocorreu em São Paulo, onde essa tensão era mais branda). Entretanto, em Buenos Aires, isso não impediu a implantação de uma "sociologia científica" na universidade, como a de Germani, que, apesar de orientar-se por questões politicamente relevantes - suas análises sobre o peronismo são emblemáticas -, foi sempre ciosa na utilização dos procedimentos científicos. Nessa cidade, a solidez de seu sistema acadêmico (estabelecido desde o século XIX) e a pressão social exercida pela nova classe média urbana a favor da universidade constituíram contrapesos às recorrentes intervenções políticas até meados da década de i960, a partir de quando as ditaduras militares sucessivas praticamente bloquearam as condições de existência da vida acadêmica na Argentina até a abertura democrática de I983. No Rio de Janeiro, diferentemente, as intervenções políticas realizadas 
durante a era Vargas (e a presença do Estado como promotor direto da vida intelectual) não encontraram resistência equivalente numa instituição universitária recém-criada (I935), nem na sociedade na qual estava inserida, que não contava com uma classe média dinâmica como as de Buenos Aires e São Paulo, o que limitou o desenvolvimento científico da sociologia moderna na Universidade do Brasil, no Rio de Janeiro. ${ }^{20}$

Passemos agora ao ponto central desta comparação. Como explicar o fato de Gino Germani e Florestan Fernandes terem se constituído, quase simultaneamente, como "chefes de escola" entre as décadas de I950 e I960? A condição geral e necessária para o surgimento coetâneo dessas "escolas" sociológicas foi a preexistência de organizações acadêmicas modernas nos dois países, o que diferenciou, como vimos anteriormente, os casos brasileiro e argentino em relação a outros latino-americanos, nos quais não se constituíram organizações desse tipo nem "escolas", até o momento considerado. A tal circunstância associou-se o contexto internacional favorável ao estabelecimento dessa disciplina na América Latina, desde o final da Segunda Guerra Mundial (Blanco, 2007).

As organizações acadêmicas nas quais os dois sociólogos atuaram eram, entretanto, muito distintas, e condicionaram suas trajetórias diferentemente. Já mencionamos o fato de que o sistema educacional argentino construído desde o final do século XIX transformou radicalmente as condições de produção e recepção da atividade intelectual. Sua abrangência e profundidade implicaram a inclusão quase imediata de setores novos da sociedade, sobretudo, filhos da imigração massiva num campo intelectual recente, mas extremamente dinâmico, que se organizou na Argentina, centralizado em Buenos Aires, entre as últimas décadas do século XIX e as primeiras do XX. A constituição de um público leitor considerável promoveu a consolidação de um mercado cultural predominantemente privado que permitiu uma profissionalização significativa da atividade intelectual e artística, favorável aos destituídos de nome e fortuna que postulavam ascender e afirmar-se por tais vias. Esse movimento inclusivo não se deu, entretanto, sem tensões. Ao contrário, provocou forte reação xenófoba e classista da elite intelectualizada previamente estabelecida que, sentindo-se ameaçada, moveu-se pela necessidade de contra-atacar tais "invasores" num meio que até então lhe era exclusivo. Tal situação explica, por exemplo, a composição social de suas vanguardas artísticas na década de I920, claramente polarizadas entre membros de famílias tradicionais, os de Florida, e os descendentes de imigrantes, nucleados no grupo de Boedo. ${ }^{21}$ Explica, também, as disputas que se prolongariam no século XX entre os críticos literários, em sua maioria filhos de imigrantes formados na FFyL e os escritores criollos, nucleados na revista Sur (Jackson \& Blanco, 20I I).

Diretamente associada a esse contexto, a FFyL da UBA seria uma das instituições acadêmicas mais diretamente envolvidas na modernização do sistema universitário argentino. Em seu interior, entretanto, a sociologia não fi- 
gurou imediatamente como uma disciplina autônoma, nem contou com o suporte de missões estrangeiras. Atrelada como vimos a outros cursos, permaneceu relativamente marginalizada até a década de I950, dependente de iniciativas frágeis e fragmentadas, se comparadas ao que se deu no Brasil desde a década de i930. A trajetória descontínua e desamparada (ele não teve mestres) de Gino Germani se inscreve nesse processo como uma exceção, uma vez que antes dele quase nada havia que sinalizasse a possibilidade de um arranque como o que empreendeu. No terreno estrito da sociologia, não podemos esquecer, foi um autodidata que se afirmou por estratégias variadas num contexto favorável em geral, pela importância da universidade e pelo dinamismo da cena cultural portenha, mas desfavorável em particular, pela posição marginal que os sociólogos detinham nesses dois âmbitos. O contexto pós-peronista sacudiria esse quadro e lhe propiciaria a possibilidade de atuar como o principal artífice da institucionalização universitária da sociologia na Argentina e, também, como intérprete agudo e privilegiado dos impasses da modernização do país.

Contrastado ao sistema educacional argentino, o que se estruturou timidamente no Brasil desde o Império foi sempre restritivo em todos os níveis e, especialmente, em sua parte superior, nucleada nas carreiras tradicionais e profissionalizantes de direito, engenharia e medicina, ensinadas em escolas superiores isoladas umas das outras (espelhadas, de certa maneira, no modelo francês das grands écoles) e voltadas a uma fração mínima da sociedade. As reformas educacionais formuladas na década de 1920 e implementadas no decênio seguinte em São Paulo e no Rio de Janeiro remediaram esse quadro sem alterá-lo em profundidade, se considerada a possibilidade da construção de um sistema universitário nacional e unificado, ${ }^{22}$ à maneira argentina. A criação da Universidade do Distrito Federal (UDF), depois Universidade do Brasil, e da USP na década de I930, restringiram aos dois principais estados do país uma vida universitária incipiente e elitista ${ }^{23}$ que, não obstante, favoreceu direta e fortemente o desenvolvimento da sociologia no país. Para ambas foram recrutados professores estrangeiros, decisivos à aclimatação prolongada de tradições teóricas e de pesquisa, que seriam encarnadas pelas primeiras gerações de estudantes dessas instituições e, também, da ELSP em São Paulo. A comparação com o caso argentino, onde não houve missões oficiais para o ensino de sociologia, reforça ainda mais a importância do papel desempenhado pelos professores estrangeiros no estabelecimento das bases organizativas e intelectuais dessa disciplina no Brasil (tanto em São Paulo, como no Rio de Janeiro). Explicita, ainda, em relação à trajetória de Florestan, que ela se inscreveu numa experiência compartilhada com outros membros de sua geração, todos diretamente beneficiados pelas oportunidades abertas pela universidade então recém-criada, principalmente pela Faculdade de Filosofia, Letras e Ciências Humanas (FFLCH-USP). Diferentemente de Germani, ele contou com a retaguarda poderosa de seus professores e, também, com a integração propiciada pelo 
grupo de colegas a que pertencia, apesar dos conflitos mais ou menos pronunciados, derivados das origens sociais divergentes e das disputas por posições nas quais estavam envolvidos. Ressaltadas as diferenças sociais, vem à tona seu "destino ímpar" (Garcia, 200I); descontadas as mesmas o percebemos antes como um membro destacado de uma geração igualmente destacada, resultante das circunstâncias extremamente favoráveis (e desafiantes) que encontraram nos primeiros anos de funcionamento da Universidade de São Paulo. ${ }^{24}$

Devemos notar, ainda, que os diferentes padrões de relação entre a esfera acadêmica e a política, vigentes em cada caso, condicionaram as escolhas temáticas dos personagens em questão. Os programas liderados por Florestan Fernandes e por Gino Germani na década de I960 se articularam em torno de uma sociologia da modernização; a primeira centrada na análise dos condicionantes sociais do desenvolvimento econômico capitalista e das respostas políticas dos diferentes agentes envolvidos em tal processo (Fernandes, I968; I975); a segunda, focada no estudo das transformações da estrutura social e de seu impacto na ordem política (Germani, I962a; I969). Ambos se inscreveram num mesmo contexto geral, o do pós-guerra, em que tais temáticas ganharam importância em toda a América Latina, tanto no campo intelectual como político. Os itinerários que os conduziram a tais problemas foram, entretanto, diferentes. Partindo de temas "frios" como o folclore e as sociedades indígenas, a questão racial marcaria para Florestan a passagem para os temas "quentes", relacionados ao problema da transição do trabalho escravo para o trabalho assalariado, eixo da discussão posterior sobre a formação da sociedade de classes no Brasil. No caso de Germani, as pesquisas sobre a modernização tiveram origem nos debates extremamente politizados sobre a imigração e o peronismo. Florestan moveu-se da ciência à política, Germani trilhou caminho inverso.

A importância que teve a antropologia (o estudo de sociedades indígenas, especificamente) na primeira fase da carreira acadêmica de Florestan é reveladora, ainda, das diferentes configurações disciplinares no interior das quais a sociologia estava inscrita em cada caso. Em São Paulo, tanto os professores da missão francesa na USP, como os norte-americanos na ELSP, em função das tradições disciplinares das quais provinham, favoreceram a institucionalização universitária da sociologia como parte de um conjunto designado como "ciências sociais", que incluiria também a antropologia e a ciência política. Na Argentina, em função de ter sido introduzida no interior dos cursos de direito, letras ou filosofia, a sociologia evoluiu subordinada aos delineamentos gerais de tais cursos, para depois se constituir como disciplina independente. Entre as relações estabelecidas com outras disciplinas, prevaleceu, como vimos anteriormente, a aproximação estreita com a história.

Semelhantes pela condição de outsiders (Miceli, 2012), pelo movimento de ascensão social possibilitado pela adesão total de ambos à vida acadêmica, 
as carreiras de Germani e Florestan tiveram, não obstante, feições distintas. A primeira foi descontínua (lembramos que Germani sequer cursou pós-graduação), afetada mais diretamente pelas oscilações da política argentina que atingiram diretamente (em graus diversos) as instituições acadêmicas e pela temporalidade mais distendida e lenta da institucionalização acadêmica da sociologia. A segunda foi contínua, transcorrida normalmente no interior da universidade, blindada em relação à política, na qual essa disciplina havia recebido um impulso extraordinário das missões estrangeiras, embora bloqueada no final dos anos de ig6o pela ditadura militar, estabelecida em I964. ${ }^{25}$

A continuidade característica da carreira de Florestan relaciona-se, de modo geral, com a maior estabilidade do sistema político brasileiro e com o padrão de relacionamento menos conflituoso entre intelectuais e Estado vigente nesse país. Como vimos, sobretudo em São Paulo, desde a criação da USP, as esferas política e acadêmica permaneceram distanciadas. Na Argentina, estiveram muito mais entrelaçadas, ${ }^{26}$ prevalecendo, a partir da reforma universitária de I9I8 (que instituiu uma tradição de autonomia acadêmica), uma relação de oposição entre intelectuais e Estado (Sigal, I99I). Esse processo implicou, também, a conversão da universidade em um ator político importante. Por isso mesmo, sofreria seguidas intervenções durante todo o século (I930, I943, I946, I955, I966, I976).

Outra diferença entre os sociólogos diz respeito aos graus de abertura e articulação internacional dos projetos desenvolvidos em São Paulo, Rio de Janeiro e Buenos Aires. Florestan Fernandes, alicerçado na forte tradição uspiana estabelecida pelos professores estrangeiros, foi quem mais resistiu à internacionalização como estratégia para o desenvolvimento da disciplina e, sobretudo, para a capacitação do próprio grupo. Nessa direção, não estimulou os membros de sua equipe a saírem do país para realizar o doutorado, nem participou ativamente das articulações que tiveram lugar na América Latina na segunda metade da década de I950, visando a criação de organismos regionais como a FLACSO (I957) e o CLAPCS (I957), nas quais Gino Germani teve papel decisivo (Blanco, 2007). Diferentemente de Florestan, Germani enviou quase toda sua equipe ao exterior, como uma tentativa de remediar a ausência de uma tradição nacional. No Brasil, quem participou diretamente de tais empreendimentos foi Costa Pinto, no Rio de Janeiro. Podemos especular que o insulamento do projeto de Florestan teria como lastro a estabilidade do processo de desenvolvimento da sociologia no interior da USP, antes do golpe. Sintomaticamente, o próprio Florestan buscaria apoio e articulações externas diante da perseguição movida pela ditadura militar. O investimento que fez Germani (e também Costa Pinto, no Rio de Janeiro) para fortalecer redes internacionais seria um contrapeso à vulnerabilidade institucional das universidades em que estavam inseridos, derivada, sobretudo, de sua implantação em cidades (ambas capitais federais) mais diretamente afetadas pelas oscilações políticas. 
Resta ainda discutir comparativamente as relações de Germani e Florestan com as tradições intelectuais nacionais. Ambos se distanciaram dessas tradições incorporando linguagens, esquemas conceituais e metodologias estrangeiras em meio a disputas com os ensaístas, que nas décadas de i930 e I940 produziram as interpretações mais consagradas sobre os processos de formação histórica e/ou de construção de identidades das duas sociedades nacionais. Houve, entretanto, diferenças. Florestan combateu mais explicitamente os ensaístas, mas absorveu suas obras, incorporando temas, perspectivas teóricas e interpretações. Germani foi discreto no enfrentamento, mas afastou-se radicalmente das perspectivas defendidas pelos ensaístas (Jackson \& Blanco, 2013). ${ }^{27}$

Finalmente, se a comparação realizada explicita o condicionamento da trajetória incomum de Florestan pelas condições favoráveis com as quais se deparou na Universidade de São Paulo juntamente com seus colegas de geração, revela, também, que a compreensão sociológica de uma carreira como a de Germani exige outras mediações, uma vez que ela se constituiu mais isoladamente - com pouca ou nenhuma retaguarda no âmbito específico de sua atividade -, embora apoiada num sistema social e cultural extremamente dinâmico para transpor com recursos variados (incluindo o autodidatismo) os obstáculos que tinha diante de si.

Recebido em I4/06/20I3 | Aprovado em I4/I I/2013

\begin{abstract}
Alejandro Blanco é mestre em Sociologia da Cultura pela Universidade Nacional General San Martín e doutor em História pela Universidade de Buenos Aires (UBA), onde também se graduou em Sociologia. Atualmente é professor de Sociologia na Universidade Nacional de Quilmes, membro do Centro de História Intelectual desta universidade e pesquisador do Conselho Nacional de Investigações Científicas e Técnicas (CONICET). É autor de Razón y modernidad. Gino Germani y la sociología en la Argentina (2006) e de numerosos artigos sobre história intelectual.

Luiz Carlos Jackson é livre-docente e professor do Departamento de Sociologia da Faculdade de Filosofia, Letras e Ciências Humanas da Universidade de São Paulo (FFLCH/USP), autor de A tradição esquecida. Os Parceiros do Rio Bonito e a sociologia de Antonio Candido (2002) e de artigos em revistas especializadas nacionais e estrangeiras, centrados na história das ciências sociais no Brasil e na América Latina.
\end{abstract}




\section{NOTAS}

* Agradecemos muito os juízos e sugestões dos pareceristas da revista, que nos permitiram melhorar o argumento aqui desenvolvido. Este texto é o eixo de um trabalho mais abrangente sobre o desenvolvimento da sociologia no Brasil e na Argentina, em vias de publicação como livro.

I Além do texto de Sergio Miceli (2012), que compara as duas trajetórias, remetemos o leitor ao livro recente de Antonio Brasil (2013), que analisa os esquemas analíticos mobilizados pelos dois sociólogos.

2 Foram eles o espanhol José Medina Echavarría, entre I958 e I960; o suíço Peter Heintz, entre I960 e I965; e o brasileiro Gláucio Ary Dillon Soares, entre I966 e I 968.

3 Seguindo a Joseph Ben-David (I97I), entendemos por "sistema acadêmico moderno" um modo de organização universitária que integra ensino e pesquisa, propiciando a formação de grupos de pesquisadores e promovendo sua profissionalização. Tal configuração teria aparecido inicialmente na Alemanha, durante o século XIX, e alcançaria sua máxima expressão no século XX, nos Estados Unidos.

4 Sublinhamos que apesar das tentativas dos outros líderes mencionados - Raúl Orgaz, Ricardo Levene e Alfredo Poviña, na Argentina; Donald Pierson, Roger Bastide, Maria Isaura Pereira de Queiroz, Costa Pinto e Guerreiro Ramos, no Brasil - e da importância que tiveram na institucionalização da disciplina, apenas Florestan Fernandes e Gino Germani exerceram o papel de "chefe de escola". Por isso mesmo, nossa comparação concentra-se nos casos de Buenos Aires e São Paulo e nessas duas figuras.

5 Isso significa tanto que os passos anteriores possibilitaram seu casamento como que este lhe propiciou uma base para o arranque profissional posterior.

6 Para uma análise da posição assumida por Germani em relação ao ensaísmo argentino, ver Blanco \& Jackson (2013).

7 O texto foi elaborado a partir de um curso que Germani ofereceu no CLES no mesmo ano e publicado na revista dessa instituição, Cursos y Conferências.

8 A imigração europeia teve impacto extraordinário na Argentina. Até I920, o país recebeu a maior proporção de imigrantes europeus no mundo. Segundo o censo de I9I4, 30\% 
da população argentina era imigrante. No Brasil, em I920, os estrangeiros representavam apenas (aproximadamente) $5 \%$ da população. Embora a imigração não tenha sido um fato irrelevante para a discussão pública e o debate intelectual no caso brasileiro, seu interesse esteve subordinado às controvérsias relativas à mudança no regime de trabalho e aos efeitos possíveis em termos do branqueamento de sua população. É sugestivo que os trabalhos mais importantes sobre a questão da imigração até a década de I970, aproximadamente, tenham sido escritos por estrangeiros, como Samuel Lowrie (I938), Emílio Willems (I940) e Michael Hall (I 969). Na Argentina, o tema da imigração esteve, desde o final do século XIX, e durante quase todo século $\mathrm{XX}$, no centro do debate político e intelectual (Avellaneda, I980; Jitrik, I980; Onega, I982).

9 O termo se refere a um grupo de pesquisadores da história argentina reunido no Instituto de Investigações Históricas da FFyL da UBA, desde a primeira década do século XX, que impulsionou a institucionalização e a profissionalização dessa disciplina, reivindicando uma orientação mais científica à mesma. Seus membros mais destacados foram: Diego L. Molinari, Ricardo Levene, Enrique Guiñazú, Luis M. Torres, Emilio Ravignani y Rómulo Carbia.

Io Para que o leitor brasileiro possa dimensionar melhor a importância da inversão interpretativa proposta por Germani na análise do impacto da imigração massiva - desde o final do século XIX, os imigrantes europeus foram muito estigmatizados pela elite intelectual argentina tradicional - é possível compará-la à que realizou Gilberto Freyre no Brasil nos anos de I930 (apesar de o brasileiro ter como referência principal o problema da formação e da identidade nacional, e o ítalo-argentino, a questão da modernização), afirmando a positividade do negro e do mestiço em oposição às avaliações anteriores do fenômeno, por meio das quais eram entendidos como obstáculos ao progresso do país. Esta pequena digressão se justifica pela importância que esses temas tiveram nos debates intelectuais travados nos dois países durante quase todo o século $\mathrm{XX}$ : a questão racial no Brasil e a da imigração na Argentina.

I I O mesmo se pode presumir para a reorientação temática do historiador José Luis Romero, do medievalismo para a histó- 
ria argentina, que teria sido influenciada diretamente pela crise política derivada do peronismo e de sua dissolução.

I 2 Nos dois momentos referidos, antes e depois de I930, as taxas de mobilidade social ascendente e descendente se mantiveram, somadas, ao redor de $70 \%$.

I3 Cabe citar: "Passei dez anos ao lado de Germani [...] como um membro suspeito [...] eu era um homem do 'antigo regime' da faculdade, único sobrevivente de um instituto infeccionado por Dilthey, Freyer e Alfred Weber [...]. Mas tinha, ademais, outras marcas: um espantoso passado peronista e, pior ainda, nacionalista e católico. [...] era a ovelha negra daquele departamento de sociologia e a lição foi de tolerância, brindada por um intolerante" (Imaz, I977: I 28-I32).

I4 Também foram enviados membros do grupo à Europa e ao Chile (FLACSO). Entre os já mencionados, Murmis foi aos Estados Unidos, Graciarena à Inglaterra e Jose Luis de Imaz à França. Outros pesquisadores e professores incorporados posteriormente, como Silvia Sigal (Inglaterra), Eliseo Verón (França) também foram enviados. Em poucos anos, mais de vinte integrantes do Instituto e do Departamento de Sociologia viajaram ao exterior. Um detalhe significativo foi a imposição do exame em inglês para ingressar na graduação em sociologia, exigência feita por Germani.

I5 O ponto fraco dessa forma organizacional talvez tenha sido a ênfase na graduação e a inexistência de um programa de pós-graduação, como os que se desenvolveram em São Paulo desde os anos de I940 na ELSP (mestrado) e na FFCL-USP (doutorado).

I6 Evitamos, neste texto, reconstruir a trajetória de Florestan, já muito conhecida pelo público brasileiro e sobre a qual há vasta bibliografia (ver, sobretudo, D’Incao, I987; Arruda, I995; Martinez, I998; Garcia, 2002; Lahuerta, 2005; Rodrigues, 20I0) mobilizando neste item apenas seus traços mais significativos, em função da comparação visada.

I7 Na América Latina, São Paulo e Buenos Aires foram as cidades que receberam maior número de imigrantes europeus entre o final do século XIX e o começo do século XX. A Argentina recebeu a maior proporção de imigrantes europeus no mundo nesse período. Segundo o censo de I9I4, 30\% da 
população argentina era imigrante. No Brasil, em I920, os estrangeiros representavam apenas (aproximadamente) $5 \%$ da população. Em Buenos Aires, no ano de I9I4, do total de quase 1.500.000 habitantes, 49\% eram imigrantes. Em São Paulo, em I920, a população era de 580.000 pessoas e os estrangeiros constituíam 35\%. Na cidade do Rio de Janeiro, também em I920, os imigrantes eram I5\% (Fausto \& Devoto, 2008; Bernasconi \& Truzzi, 2000). Os dados numéricos oferecem uma ideia bastante precisa a respeito da imigração nos dois países: seu impacto na Argentina foi muito mais significativo. Comparadas as magnitudes da imigração nessas cidades, vemos que São Paulo se aproxima de Buenos Aires, enquanto o Rio de Janeiro se distancia.

I 8 Em contraposição a uma "classe média tradicional", constituída desde o século XIX (como no caso do Rio de Janeiro), dependente dos setores dominantes tradicionais e proveniente, sobretudo, de seus ramos declinantes. Vinculada ocupacionalmente à burocracia estatal, identificava-se social e politicamente com aqueles mesmos setores dominantes. A "nova classe média" proveio da imigração massiva e se inseriu progressivamente nos setores modernos da economia (Graciarena, I967; Pinheiro, I990). Cabe citar uma observação aguda de Roger Bastide a respeito desse processo, diferenciando as experiências paulistana e carioca: [sobre a classe média] "encontramos, sem dúvida, fenômenos análogos no Rio de Janeiro. Mas como o número de estrangeiros ou de filhos de estrangeiros não portugueses é aí menor, o choque de valores é menos dramático: tudo se passa entre brasileiros. Daí uma diferença capital entre a classe média do Rio de Janeiro e a de São Paulo. A presença do governo e de todo o maquinismo administrativo, no Rio de Janeiro, faz com que sua classe média seja principalmente uma classe média de funcionários ou de burocratas. A industrialização mais avançada de São Paulo faz de sua classe média uma classe de pequenos fabricantes e de empregados." (Bastide, I97I: I55-I56).

I9 Segundo a interpretação de Lúcia Lippi de Oliveira (I995), diversas pesquisas importantes realizadas no CBPE e no CLAPCS, evidenciariam o desenvolvimento das ciências sociais cariocas na década de I950, implicando a necessidade de revisar o esquema de interpretação mencionado. Nessa 
mesma direção, Nísia Trindade Lima (I 999) e Gláucia Villas Boas (2006) reforçaram a ideia de que o caso do Rio de Janeiro não deveria ser tomado como um desviante da experiência paulista, mas como uma modalidade específica de institucionalização. Para o nosso argumento, contudo, cabe destacar o enraizamento universitário da sociologia paulista, que teria condicionado diretamente a emergência da escola sociológica liderada por Florestan. Essa circunstância particular justifica a ênfase analítica no caso de São Paulo.

20 O que não significa que não houve, nesse período, sociologia científica no Rio de Janeiro, mas sim que o seu desenvolvimento dependeu de centros e institutos independentes, o que, provavelmente, limitou as possibilidades de sociólogos como Guerreiro Ramos e Costa Pinto aglutinarem grupos de pesquisadores, ou seja, de se tornarem "chefes de escola", como foram Gino Germani e Florestan Fernandes.

2I Sobre as vanguardas argentinas, ver texto de Adolfo Prieto (1969), publicado na revista Tempo Social (2009). Consultar também Sarlo \& Altamirano (I983) e Schwartz (2002).

22 Isso só ocorreria durante a ditadura militar (I964-I985).

23 Embora os novos cursos criados, sobretudo na FFCL-USP, apresentassem um padrão mais democrático de recrutamento social, a favor de mulheres, filhos de imigrantes e membros da classe média em geral, o sistema universitá rio brasileiro era elitista porque atingia uma parcela muito pequena da população do país, enquanto na Argentina era muito mais abrangente. A propósito, Gino Germani apresentou dados sugestivos, relativos ao ano de i950: na Argentina, havia, então, 756 estudantes universitários para cada Ioo mil habitantes; no Brasil, eram I I7 para cada Ioo mil. A Argentina ocupava o terceiro lugar no ranking mundial, enquanto o Brasil estava na $58^{\mathrm{a}}$ posição (Germani \& Sautu, I965).

24 Gostaríamos de aclarar, para evitar mal-entendidos, que não discordamos da interpretação de Sylvia Garcia, nem da importância por ela atribuída à origem social de Florestan para entender sua trajetória, em relação à de seus colegas; mas a comparação com Germani sugere um matiz a ser levado em conta, na medida em que explicita a dívida de Florestan com a experiência privilegiada e compartilhada com seus colegas de geração no interior da universidade, sob a influência direta dos professores estrangeiros. 
25 Como dito anteriormente, Florestan foi o caso emblemático das perseguições pontuais movidas pela ditadura militar aos professores universitários no Brasil; o outro lado da moeda, não obstante, e diferentemente do que ocorreu na Argentina, residiu na política educacional dos governos militares, que levou à expansão do sistema educacional superior e das ciências sociais especificamente nesse período (I964-I985).

26 “O Brasil não é a Argentina. Neste último país, cada ruptura política se traduz numa grande crise das instituições intelectuais - as universidades em primeiro lugar -, na substituição das camadas de intelectuais que presidem a definição das propriedades do campo intelectual e de suas formas de classificação, na desestabilização das representações da política no meio intelectual (Sigal, I986). Nada disso ocorre no Brasil. As instituições persistem, apesar da repressão política. Os intelectuais continuam a se atribuir uma legitimidade propriamente científica e não é por acaso que privilegiam ainda mais o tema da "profissionalização'" (Pécaut, I990: 262).

27 Não devemos deduzir dessa diferença, contudo, que Germani teria ignorado completamente a tradição intelectual argentina, uma vez que sua obra se inscreve na linhagem do melhor ensaísmo político argentino, podendo ser entendida como uma atualização dos questionamentos feitos por Sarmiento, no século XIX, sobre as bases sociais do autoritarismo político que vigia em seu tempo com o rosismo.

\section{REFERÊNCIAS BIBLIOGRÁFICAS}

Almeida, Maria Hermínia Tavares de. (I989). Dilemas da institucionalização das ciências sociais no Rio de Janeiro. In: Miceli, Sérgio (org.). História das ciências sociais no Brasil. São Paulo: Vértice/Idesp/Finep, vol. I, p. I89-2 I6.

Altamirano, Carlos. (200I). Bajo el signo de las masas (1943I973). Buenos Aires: Ariel (Biblioteca do Pensamento Argentino, tomo IV).

Altamirano, Carlos \& Sarlo, Beatriz. (1983). Ensayos argentinos. Buenos Aires: CEAL.

Arruda, Maria Arminda do Nascimento. (200I). Metrópole e cultura. São Paulo: EDUSC. 
Arruda, Maria Arminda do Nascimento. (1995). A sociologia no Brasil: Florestan Fernandes e a "escola paulista". In: Miceli, Sergio (org.) História das ciências sociais no Brasil. São Paulo: Sumaré/Idesp/Fapesp, vol. 2, p. I07-23I.

Avellaneda, Andrés. (I980). El naturalismo y E. Cambaceres. In: Historia de la literatura argentina. (Vol. 2, Del romanticismo al naturalismo). Buenos Aires: CEAL, p. I45-I68.

Bastide, Roger. (I97I). Brasil, terra de contrastes. São Paulo: Difusão Europeia do Livro.

Ben-David, Joseph. (I97I). The scientific role in society. A comparative study. New Jersey: Prentice-Hall.

Bernasconi, Alicia \& Truzzi, Oswaldo. (2000). Las ciudades y los inmigrantes: Buenos Aires y São Paulo (I880-I930). In: Brasil-Argentina, a visão do outro. Buenos Aires: Fundación Centro de Estudios Brasileiros/Funag, p. 205-242.

Blanco, Alejandro. (20I3). José Luis Romero y Gino Germani: la inmigración masiva y el proyecto de una comprensión histórico-sociológico de la Argentina moderna. In: Burucúa, José Emilio; Devoto, Fernando \& Gorelik, Adrián (orgs.). José Luis, vida historia, ciudad y cultura. Buenos Aires: UNSaM, p. 273-29I.

Blanco, Alejandro. (20Io). José Medina Echavarría y el proyecto de una sociología científica. In: Pereyra, Diego (org.). El desarrollo de las ciencias sociales. Tradiciones, actores e instituciones en Argentina, Chile, México y América Central. Série Cuadernos de Ciencias Sociales, I53, p. I7-34.

Blanco, Alejandro. (2007). Ciências sociais no Cone Sul e a gênese de uma elite intelectual (I940-I965). Tempo Social. Revista de Sociologia da USP, I9/I, p. 89-I I4.

Blanco, Alejandro. (2006). Razón y modernidad. Gino Germani y la sociología en la Argentina. Buenos Aires: Siglo XXI.

Blanco, Alejandro. (2005). La Asociación Latinoamericana de Sociología: una historia de sus primeros congresos. Sociologías, 7/I4, p. 22-49.

Blanco, Alejandro \& Jackson, Luiz Carlos. (2013). Sociólogos versus ensayistas en Brasil y Argentina. Estudios Sociológicos de El Colegio de México, XXXI/92, p. 397-436

Blanco, Alejandro \& Jackson, Luiz Carlos. (20 I I). Crítica literária e sociologia no Brasil e na Argentina. Tempo Social. Revista de Sociologia da USP, 23/2, p. I3-40. 
Brasil Jr., Antonio da Silveira. (2013). Passagens para a teoria sociológica: Florestan Fernandes e Gino Germani. São Paulo: Hucitec.

Brunner, José Joaquín. (1985). Los orígenes de la sociología profesional en Chile. Documento de Trabajo $\mathrm{n}^{\circ} 260$, Programa FLACSO-Santiago de Chile.

Buchbinder, Pablo. (2005). Historia de las universidades argentinas. Buenos Aires: Sudamericana.

Buchbinder, Pablo. (I 997). Historia de la Facultad de Filosofía y Letras, Universidad de Buenos Aires. Buenos Aires: EUDEBA. Bulmer, Martin. (1984). The Chicago school of sociology. Chicago: University of Chicago Press.

Castañeda, Fernando. (I990). La constitución de la sociología en México. In: UNAM (org.), Desarrollo y organización de las ciencias sociales en México. México: UNAM, p. 47-6I.

Coser, Lewis. (1968). Hombres de ideas. El punto de vista de un sociólogo. México: Fondo de Cultura Económica.

Cunha, Luiz Antônio. (2007), A universidade temporã. São Paulo: Ed.Unesp.

De Imaz, José Luis. (I977). Promediando los cuarenta. Buenos Aires: Sudamericana.

D’Incao, Maria Angela (org.). (1987). O saber militante: ensaios sobre Florestan Fernandes. Rio de Janeiro: Paz e Terra.

Devoto, Fernando (org.). (I993). La historiografía argentina en el siglo veinte. Buenos Aires: CEAL (2 vols.).

Devoto, Fernando \& Fausto, Boris. (2004). Argentina/Brasil I 850-2000. Un ensayo de historia comparada. Buenos Aires: Sudamericana.

Fernandes, Florestan. (I98I). Sociedade de classes e subdesenvolvimento. Rio de Janeiro: Zahar.

Fernandes, Florestan. (I975). A revolução burguesa no Brasil: ensaio de interpretação sociológica. Rio de Janeiro: Zahar.

Garcia, Afrânio. (2006). Circulación internacional y formación de una "escuela de pensamiento" latinoamericana (1945-2000). Prismas, Revista de Historia Intelectual, Io, p. I I35. Anuario del Grupo Prismas, Universidad Nacional de Quilmes.

Garcia, Sylvia. (2002). Destino ímpar. São Paulo: Ed. 34. 
García Bouza, Jorge \& Verón, Eliseo. (1967). Epílogo de una crónica: la situación de la sociología en Argentina. Revista Latinoamericana de Sociología, 3/I, p. 9 I-95.

Germani, Ana. (2004). Gino Germani. Del antifascismo a la sociologia. Buenos Aires: Taurus.

Germani, Gino. (1978). Authoritarianism, fascism and national populism. New Brunswick, NJ: Transaction Books.

Germani, Gino. (1 969). Sociología de la modernización. Buenos Aires: Paidós.

Germani, Gino. (1964). La asimilación de los inmigrantes en la Argentina y el fenómeno del regreso de la inmigración reciente. In: Trabajos e investigaciones del Instituto de Sociología, Publicación Interna, I4. Departamento de Sociología, Facultad de Filosofía y Letras, Universidad de Buenos Aires. Germani, Gino. (1962a). Política y sociedad en una época de transición. De la sociedad tradicional a la sociedad de masas. Buenos Aires: Paidós.

Germani, Gino. (1962b). La inmigración masiva y su papel en la modernización del país. In: Política y sociedad en una época de transición. De la sociedad tradicional a la sociedad de masas. Buenos Aires: Paidós, p. I79-2I6.

Germani, Gino. (1956a). La sociología científica. Apuntes para su fundamentación. México: Instituto de Investigaciones Sociales, Universidad Nacional México.

Germani, Gino. (I956b). Informe preliminar del Instituto de Sociología sobre las encuestas entre estudiantes universitarios. Centro, I 2, p. 34-46.

Germani, Gino. (1955). Estructura social de la Argentina. Análisis estadístico. Buenos Aires: Solar.

Germani, Gino. (1946). Teoría e investigación en la sociología empírica. Buenos Aires, inédito.

Germani, Gino, Graciarena Jorge \& Halperin Donghi, Tulio (orgs.). (1965). Argentina, sociedad de masas. Buenos Aires: EUDEBA.

Germani, Gino \& Sautu, Ruth. (1965). Regularidad y origen social de los estudiantes universitários. In: Investigaciones y trabajos del Instituto de Sociología. Instituto de Sociología, Facultad de Filosofía y Letras, Universidad de Buenos Aires, p. 9-26. 
Graciarena, Jorge. (1967). La crisis de las clases medias. In: Poder y clases sociales en el desarrollo de América Latina. Buenos Aires: Paidós, p. I36-2I 2.

Hall, Michael. (1969). The origins of mass migration in Brazil, I87 I-I 9I4. Nova York: Columbia University Press.

Halperin Donghi, Tulio. (I986). Un cuarto de siglo de historiografía argentina (I960-I985). Desarrollo Económico, 25/I00, p. 487-520.

Halperin Donghi, Tulio \& Di Tella, Torcuato (orgs.). (I969). Los fragmentos del poder. Buenos Aires: Jorge Álvarez.

Jitrik, Noé. (1980). El ciclo de la bolsa. In: Historia de la literatura argentina. (Vol. 2, Del romanticismo al naturalismo). Buenos Aires: CEAL, p. I45-I68.

Keinert, Fábio Cardoso. (20I I). Cientistas sociais entre ciência e política (Brasil, I968-I985). Tese de Doutorado. FFLCH/Universidade de São Paulo.

Kratochwill, Germán. (I970). El estado de las ciencias sociales en la Argentina. Documento de Trabajo, 67. Buenos Aires: Centro de Investigaciones Sociales, Instituto Torcuato Di Tella, p. 2-35.

Lahuerta, Milton. (2005). Em busca da formação social brasileira: marxismo e vida acadêmica. Perspectivas. Revista de Ciências Sociais, 28, p. I57-I86.

Lima, Nísia Trindade. (I999). Um sertão chamado Brasil. Intelectuais e representação geográfica da identidade nacional. Rio de Janeiro: Revan/IUPERJ-UCAM.

Lowrie, Samuel. (I 938). Imigração e crescimento da população no estado de São Paulo. Coleção Estudos Paulistas, 2. São Paulo, Escola Livre de Sociologia e Política.

Luna, Félix. (1987). Perón y su tiempo. Tomo I: La Argentina era una fiesta, I946-1949. Buenos Aires: Sudamericana.

Mangone, Carlos \& Warley, Jorge. (I984). Universidad y peronismo (I946-I 955). Buenos Aires: CEAL.

Martinez, Paulo Henrique (org.). (I998). Florestan ou o sentido das coisas. São Paulo: Boitempo.

Miceli, Sérgio. (20I2). Los inventores de la sociología "científica" en Brasil y en la Argentina (Florestan Fernandes y Gino Germani)". In: Ensayos porteños. Borges, el nacionalismo 
y las vanguardias. Bernal: Universidad Nacional de Quilmes, p. I 27-I 43 .

Miceli, Sérgio. (200I). Por uma sociologia das ciências sociais. In: História das ciências sociais no Brasil. São Paulo: Sumaré, p. I I-28.

Miceli, Sérgio. (1989). Condicionantes do desenvolvimento das ciências sociais. In: História das ciências sociais no Brasil. São Paulo: Vértice/Idesp/Finep, vol. I, p. 9 I-I33.

Míguez, Eduardo. (I993). El paradigma de la historiografía económico-social de la renovación de los años '6o vistos desde los años '9o. In: Devoto, Fernando (org.). La historiografía argentina en el siglo veinte. Buenos Aires: CEAL, p. IO-29 (2 vols.).

Morcilo Laiz, Álvaro. (2008). Historia de un fracaso: individuos, organizaciones y la sociología weberiana en México (I937-I957). Sociológica, 67, p. I49-192.

Murmis, Miguel. (2007). Sociologia, ciência política e antropologia: institucionalização, profissionalização e internacionalização na Argentina. In: Trindade, Helgio (org.). As ciências sociais na América Latina em perspectiva comparada. Porto Alegre: Ed. UFRGS/ANPOCS, p. 2 I-70.

Neiburg, Federico. (1998). Los intelectuales y la invención del peronismo. Buenos Aires: Alianza.

Oliveira, Lúcia Lippi. (I995). As ciências sociais no Rio de Janeiro. In: Miceli, Sérgio (org.). História das ciências sociais no Brasil. São Paulo: Sumaré, vol. 2, p. 233-307.

Onega, Gladys. (I982). La inmigración en la literatura argentina (I880-I9I0). Buenos Aires: CEAL.

Ortiz, Renato. (I990). Impressões sobre as ciências sociais no Brasil. Novos Estudos Cebrap, 27, p. I63-175.

Pécaut, Daniel. (1990). Intelectuais e a política no Brasil: entre o povo e a nação. São Paulo: Ática.

Pinheiro, Paulo Sérgio. (I990). Classes médias urbanas: formação, natureza, intervenção na vida política. In: Fausto, Boris (org.). III. O Brasil republicano (vol. 2, Sociedade e instituições, I889-I930). Rio de Janeiro: Bertrand, p. 7-37.

Pontes, Heloisa. (2010). Intérpretes da metrópole. São Paulo: Edusp. 
Poviña, Alfredo. (I94I). Historia de la sociología en Latinoamérica. México: Fondo de Cultura Económica.

Prado, Maria Ligia Coelho. (2000). Concepções de universidade e lutas políticas no Brasil e na Argentina dos anos 30. Seminário Brasil-Argentina. A visão do outro. Brasília: FUNAG, p. 61 $3-639$.

Prieto, Adolfo. (2009). Boedo e Florida. Tempo Social. Revista de Sociologia da USP, 2 I/2, p. 289-304.

Prieto, Adolfo. (1988). El discurso criollista en la formación de la Argentina moderna. Buenos Aires: Sudamericana.

Prieto, Adolfo. (1969). Boedo y Florida. Estudios de literatura argentina. Buenos Aires: Galerna, p. 29-55.

Reyna, José Luis. (2007). A institucionalização das ciências sociais no México. In: Trindade, Hélgio (org.). As ciências sociais na América Latina em perspectiva comparada. Porto Alegre: Ed. UFRGS, p. 225-308.

Reyna, José Luis. (1979). La investigación sociológica en México. In: Arguedas, Ledda et al. Sociología y Ciencia política en México (un balance de veinticinco años). México: Universidad Nacional Autónoma de México, p. 4I-62.

Rivera, Jorge. (I980). El auge de la industria cultural. In: Historia de la literatura argentina. Buenos Aires: CEAL, vol. 4, p. 577-600.

Romero, José Luis. (1996) [1946]. Las ideas políticas en Argentina. México: Fondo de Cultura Económica.

Rodrigues, Lidiane Soares. (2010). Florestan Fernandes: interlúdio (I 969-1983). São Paulo: Hucitec.

Romero, José Luis; Germani, Gino \& Halperin Donghi, Tulio. (1958). Proyecto de investigación: el impacto de la inmigración masiva sobre la sociedad y la cultura argentina $\left(2^{\mathrm{a}}\right.$ revisión). In: Trabajos de Investigación del Instituto de Sociología. Publicación Interna, I8, Universidad de Buenos Aires, Facultad de Filosofía y Letras, Departamento de Sociología, P. I-I5.

Sarlo, Beatriz. (200I). La batalla de las ideas (I 943-I973). Buenos Aires: Ariel (Biblioteca del Pensamiento Argentino, vol. 7). Sarlo, Beatriz. (I988). Una modernidad periférica. Buenos Aires: Nueva Visión. 
Schwartz, Jorge. (2002). Las vanguardias latinoamericanas. Textos programáticos y críticos. Buenos Aires: Fondo de Cultura Económica.

Sigal, Silvia. (I99I). Intelectuales y poder en la década del sesenta. Buenos Aires: Puntosur.

Tiryakian, Edward A. (I 979). The significance of schools in the development of sociology. In: Snizek, William E., Fuhrman, Ellsworth R. \& Miller, Michael K. (I979). Contemporary issues in theory and research. A metasociological perspective. Londres: Greenwood Press, p. 2 I I-233.

Vianna, Luiz Werneck. (I997). A institucionalização das ciências sociais e a reforma social: do pensamento social à agenda americana de pesquisa. In: A revolução passiva. Iberismo e americanismo no Brasil. Rio de Janeiro: Revan.

Villas Boas, Gláucia. (2006). Mudança provocada: passado e futuro do pensamento sociológico brasileiro. Rio de Janeiro: Ed. FGV.

Willems, Emilio. (I940). Assimilação e populações marginais no Brasil. Estudo sociológico dos imigrantes germânicos e seus descendentes. São Paulo: Companhia Editora Nacional. 
Palavras-chave

Sociologia;

Trajetórias intelectuais;

Projetos acadêmicos;

Institucionalização;

Florestan Fernandes;

Gino Germani.

Keywords

Sociology;

Intellectual trajectories;

Academic projects;

Institutionalization;

Florestan Fernandes;

Gino Germani.

\section{FLORESTAN FERNANDES NO}

\section{ESPELHO DE GINO GERMANI}

Resumo

O texto compara as trajetórias intelectuais de Gino Germani (I9I I-I979) e Florestan Fernandes (I920-I 995), revelando aspectos possivelmente não problematizados anteriormente pela bibliografia. Esse movimento é realizado por meio de uma reconstrução dos contextos de institucionalização da sociologia na Argentina e no Brasil, nos quais os personagens lideraram projetos acadêmicos muito ambiciosos e decisivos à legitimação dessa disciplina nos dois países.

\section{FLORESTAN FERNANDES IN}

\section{GINO GERMANI'S MIRROR}

\section{Abstract}

The article compares the intellectual trajectories of Gino Germani (I9I I-I979) and Florestan Fernandes (I920-I995) in order to reveal aspects not previously problematized in the literature. This movement is accomplished by a reconstruction of the institutionalization contexts of sociology in Argentina and Brazil, where the characters led very ambitious and decisive academic projects to the discipline legitimization in both countries. 